\title{
HUBUNGAN PERILAKU ASERTIF DENGAN KENALAN REMAJA DAN MASALAHANYA DI SMAN 2 MASBAGIK
}

\author{
LL. Zihnan Munir \\ SMA Negeri 2 Masbagik \\ zihnan1967lalu@gmail.com
}

\begin{abstract}
This study aims to determine the relationship of assertive behavior with juvenile delinquency and the problem in students of SMAN 2 Masbagik. The research design used is descriptive and correlational. The research population was 170 SMAN 2 Masbagik students. The research sample was 119 people, used by random sampling technique. The research instrument used is the psychological scale. The data analysis technique used is descriptive analysis and product moment correlation analysis. Based on the study of the assertive behavior of respondents included in the high category that is $73.95 \%$. Most of the juvenile delinquency of respondents who fall into the category is quite $64.71 \%$. Correlation analysis results obtained by the magnitude of the correlation coefficient of -0.211 . The correlation test results showed that the rxy obtained was -0.211 while the $r$ table with $N=119$ was 0.176 . Because the value of $r$ arithmetic $>r$ table $(-0.211>0.176)$ then there is a negative relationship between certive behavior and juvenile delinquency. Effective contribution of assertive variables is $4.45 \%$ of juvenile delinquency in class XI students of SMAN 2 Masbagik. The results give students the opportunity to express what students want to express without shame, students should always be assertive in their stance, honest with themselves and honest with others, always responsible for what they have done, know themselves and also have high self confidence
\end{abstract}

Keywords: Assertive Behavior, Juvenile Delinquency, SMAN 2 Masbagik.

\begin{abstract}
Abstrak: Penelitian ini bertujuan untuk mengetahui hubungan perilaku asertif dengan kenakalan remaja dan masalahnya pada peserta didik SMAN 2 Masbagik. Rancangan penelitian yang digunakan adalah deskriptif dan korelasional. Populasi penelitian adalah peserta didik SMAN 2 Masbagik sebanyak 170. Sampel penelitian sejumlah 119 orang, dipakai dengan teknik random sampling. Instrumen penelitian yang digunakan yakni skala psikologi. Teknik analisis data yang digunakan adalah analisis deskriptif dan analisis korelasi product moment. Berdasarkan penelitian perilaku asertif responden termasuk kategori tinggi yaitu 73,95\%. Sebagian besar kenakalan remaja responden yang termasuk dalam kategori cukup 64,71\%. Hasil analisis korelasi diperoleh besarnya koefisien korelasi sebesar -0,211. Hasil uji korelasi menunjukkan bahwa rxy yang diperoleh sebesar -0,211 sedangkan pada $\mathrm{r}$ tabel dengan $\mathrm{N}=119$ sebesar 0,176. Karena nilai $\mathrm{r}$ hitung $>\mathrm{r}$ tabel $(-0,211>0,176)$ maka

Fondatia : Jurnal Pendidikan Dasar

Volume 3, Nomor 2, September 2019; 103-113

https://ejournal.stitpn.ac.id/index.php/fondatia
\end{abstract}


terdapat hubungan negatif antara perilaku sertif dengan kenakalan remaja. Sumbangan efektif variabel asertif sebesar 4,45\% terhadap kenakalan remaja pada peserta didik kelas XI SMAN 2 Masbagik. Hasil memberi kesempatan kepada peserta didik untuk mengungkapkan apa yang peserta didik ingin ungkapkan tanpa adanya rasa malu, Peserta didik seharusnya senantiasa bersikap tegas dalam pendirian, jujur terhadap diri sendiri maupun jujur kepada orang lain, selalu bertanggungjawab terhadap apa yang telah dilakukannya, mengenal dirinya sendiri dan juga memiliki rasa percaya diri yang tinggi

Kata Kunci: Perilaku Asertif, Kenakalan Remaja, SMAN 2 Masbagik

\section{PENDAHULUAN}

Anak adalah tunas bangsa yang akan tumbuh dan berkembang menjadi generasi penerus. Kewajiban kita mengantarkan mereka sehingga mampu mengembangkan kepribadian, menemukan identitas dirinya seirama dengan pertambahan usianya. Masa depan bangsa dan negara menjadi tanggung jawab dan terletak dipundak generasi muda. Generasi muda dapat dikatakan mempunyai posisi yang strategis. Remaja merupakan suatu generasi yang sangat penting dalam suatu negara, namun pada kenyataannya kenakalan remaja justru malah menjadi suatu permasalahan yang sangat besar bagi negara.

Komunikasi adalah teknik yang digunakan oleh seseorang dalam membina hubungan sosial dengan lingkungannya. Komunikasi yang baik akan dapat mengekspresikan apa yang kita pikirkan ${ }^{1}$.

Komunikasi adalah setiap bentuk tingkah laku seseorang, baik berupa verbal dan non verbal yang ditanggapi oleh orang lain. Setiap bentuk tingkah laku mengungkapkan pesan tertentu, sehingga juga merupakan bentuk komunikasi. Tingkah laku verbal adalah tingkah laku dengan menggunakan kata-kata sedangkan on verbal adalah tingkah laku dengan menggunakan isyarat ${ }^{2}$. Komunikasi merupakan aspek sentral dalam hubungan antar manusia ${ }^{3}$.

\footnotetext{
${ }^{1}$ Satiadarma, Monty P. Persepsi Orang Tua Membentuk Perilaku Anak : Dampak Pygmalion di dalam keluarga. (Jakarta: Pustaka populer obor. 2001) hlm: 106

2 Supratiknya, A. Komunikasi Antarpribadi Tinjauan Psikologis. (Yogyakarta: Kanisius. 1995). Hlm: 55

3 Satiadarma, Monty P. Persepsi Orang Tua Membentuk Perilaku Anak: Dampak Pygmalion di dalam keluarga. (Jakarta: Pustaka populer obor. 2001) hlm: 95
} 
Alasan seorang remaja awal tidak dapat berperilaku asertif adalah karena mereka belum menyadari bahwa mereka memiliki hak untuk berperilaku asertif. Remaja awal dipilih, karena pada masa ini terdapat keraguan akan identitas diri sebagai seorang remaja awal karena pada masa ini individu telah merasa dewasa namun masih ada orang-orang disekelilingnya yang menyebutnya "anak remaja". Banyak pula anak remaja yang cemas atau takut untuk berperilaku asertif, atau bahkan banyak individu selain anak remaja yang kurang terampil dalam mengekspresikan diri secara asertif. Hal ini mungkin mendapatkan pengaruh dari latar belakang budaya keluarga dimana anak remaja itu tinggal, urutan anak tersebut dalam keluarga, pola asuh orang tua, jenis kelamin, status sosial ekonomi orang tua atau bahkan sistem kekuasaan orang tua ${ }^{4}$.

Seseorang hendaknya dapat berperilaku asertif untuk menunjang hubungan interpersonal yang baik dengan orang lain dalam berbagai cara dan situasi. tingkah laku asertif adalah bentuk ketrampilan sosial yang tepat untuk berbagai situasi sosial. Untuk menjalin hubungan interpersonal yang baik, seseorang membutuhkan kemampuan berperilaku asertif. Individu yang sering berperilaku tidak asertif akan merasa tidak nyaman. Apabila hal ini terjadi terus-menerus akan menimbulkan konflik intra atau interpersonal.

Penyebab para remaja terjerumus ke hal-hal negatif seperti narkoba, tawuran dan seks bebas, salah satunya disebabkan karena kepribadian yang lemah. Cirinya antara lain 1) Daya tahan terhadap tekanan dan tegangan rendah, 2) Kurang bisa mengekspresikan diri, menerima umpan balik, menyampaikan kritik, menghargai hak dan kewajiban, kurang bisa mengendalikan emosi dan agresivitas serta tidak dapat mengetasi masalah dan konflik dengan baik yang erat kaitannya dengan asertivitas.

Remaja merupakan saat dimana anak mencari jati diri. Remaja ingin mengaktualisasikan diri secara optimal. Namun sering kali cara mengaktualisasikan diri tersebut tidak mendapat respon yang baik dari pihak keluarga. Perlu satu wadah yang baik termasuk perilaku asertif yang mana perilaku ini harus dimulai dari kecil. Namun, berperilaku asertif bukanlah hal yang mudah untuk dilakukan apalagi bagi remaja.

4 Awaluddin. Assertive Behaviour on early teen. Psychology jurnal. (Jakarta: Universitas Gunadarma.2008) hlm: 2-3 
Penelitian ini berangkat dari fenomena perilaku remaja yang cenderung untuk ikut-ikutan. Bahkan untuk kenakalan yang mereka lakukan terkadang dilakukan hanya karena takut dianggap tidak gaul, dijauhi teman dan tekanan-tekanan lain dari teman sebaya. Beberapa penelitian menunjukkan bahwa remaja menjadi tidak mempunyai pendirian karena tekanan teman sebaya. Perubahan definisi sosial yang terjadi pada remaja turut pula membawa perubahan dalam bentuk hubungan dan perilaku interpersonal sehingga cenderung memunculkan pertanyaan dan masalah baru mengenai hubungan sosial. Akibatnya tidak sedikit remaja yang memiliki asertivitas rendah.

\section{KAJIAN PUSTAKA}

\section{Perilaku Asertif}

Kata asertif berasal dari kata assertive yang berarti tegas dalam pernyataannya, baik dalam mengekspresikan dirinya ataupun pendapatnya. Perilaku asertif adalah perilaku yang menampilkan keberanian untuk jujur dan terbuka dalam menyatakan kebutuhan, perasaan dan pikirannya secara apa adanya tanpa menyakiti perasaan orang lain ${ }^{5}$. Perilaku asertif merupakan sikap dimana seseorang mampu bertindak sesuai dengan keinginannya, membela haknya dan tidak dimanfaatkan orang lain. Bersikap asertif berarti mengomunikasikan apa yang kita inginkan secara jelas dengan menghormati hak pribadi kita dan orang lain. Sikap asertif merupakan ungkapan perasaan, pendapat, dan kebutuhan kita secara jujur dan wajar. Kemampuan untuk bersikap asertif sangat penting dimiliki sejak dini, karena akan membantu kita untuk bersikap tepat menghadapi situasi dimana hak-hak kita dilanggar

\section{Pengertian Kenakalan Remaja}

Masalah kenakalan remaja bukan masalah yang baru untuk diperbincangkan. Kenakalan remaja atau juvenille delinguency mempunyai makna yang tertuju kepada suatu masa tertentu, yaitu masa-masa remaja sekitar usia 13 tahun sampai dengan 21 tahun. Perbuatan seseorang remaja ketika berada pada masa pencarian identitas diri yang mengalami pertumbuhan/perkembangan dan mental belum stabil atau matang sehingga dapat dikatakan remaja merupakan masa krisis identitas. Kenakalan Remaja

5 Prabowo, Sumbodo. Membangun Perilaku Asertif pada Komunikasi antara perawat dan pasien. Psikodimensia. (Semarang: Universitas Katholik Soegijapranata. Vol.1 No.12000) hlm: 6-20 
adalah Perilaku Jahat atau Dursila, atau kejahatan atau kenakalan anak-anak muda, merupakan gejala sakit (patologis) secara sosial pada anak-anak dan remaja yang disebabkan oleh satu bentuk tingkah laku yang menyimpang.

\section{Hubungan perilaku asertif dengan kenakalan remaja}

Peserta didik berada pada usia remaja yaitu masa peralihan antara masa kanak-kanak menuju masa dewasa yang ditandai dengan perubahan fisik dan psikologis ini, remaja harus memiliki perilaku asertif agar terhindar dari perilaku menyimpang atau kenakalan remaja

Banyaknya fenomena penyimpangan perilaku yang dilakukan remaja diakibatkan karena ia tidak mau berterus terang tentang sikap dan perasaannya terhadap pergaulan teman sebaya. Adapun penyimpangan perilaku adalah semua tingkah laku yang tidak sesuai, tidak bisa diterima oleh masyarakat pada umumnya, dan tidak sesuai dengan norma sosial yang ada tetapi jika penyimpangan itu terjadi terhadap norma hukum pidana disebut kenakalan.

Kenakalan remaja yang terjadi pada peserta didik kelas XI SMAN 2 Masbagik lebih banyak disebabkan oleh pergaulan yang kaitannya dengan interaksi dan komunikasi antar teman sebaya baik itu di lingkungan teman satu kelas, satu sekolah ataupun antar kelas. Komunikasi antar teman sebaya sangat berpengaruh terhadap remaja dikarenakan dalam pergaulan antar teman yang perbedaan umurnya tidak terpaut jauh, remaja cenderung lebih suka meniru apa yang dilakukan oleh temantemannya dengan alasan apabila tidak dilakukan maka mereka akan menjauhi.

Orang tua juga sangat berperan penting dalam menjaga pergaulan anakanaknya, kesibukan orang tua yang berlebihan biasanya menyebabkan anak cenderung terlalu bebas bergaul dengan siapa saja tanpa bisa membedakan mana yang baik dan buruk karena kurangnya perhatian dari orang tua, pola asuh yang terlalu protektif dan komunikasi yang tertutup dalam keluarga.

Perilaku asertif adalah pengungkapan diri secara terbuka, tegas dan bebas atas perasaan positif dan negatif maupun tindakan mempertahankan hak mutlak dengan tetap memperhatikan perasaan orang lain. Dengan memiliki perilaku asertif maka anak akan mampu untuk mengungkapkan perasaannya tanpa menyakiti orang lain sehingga tidak menimbulkan perilaku menyimpang. 
Memiliki sikap asertif yang tinggi akan lebih mampu menjaga dirinya, tidak melakukan perilaku menyimpang atau kenakalan remaja, karena dia mampu menghargai dirinya dan mampu mengendalikan dirinya dari pengaruh orang lain dengan mengatakan tidak untuk hal-hal yang tidak sesuai dengan nilai-nilai yang diyakininya.

Orang-orang yang memiliki asertivitas yang rendah akan semakin mudah terbawa dalam pengaruh lingkungan sekitar yang negatif atau perilaku menyimpang. Perilaku asertif erat kaitannya dengan kenakalan remaja. Semakin tinggi perilaku asertif yang dimiliki individu, maka semakin rendah kenakalan remaja.yang ditimbulkan oleh individu. Hal ini senada dengan penelitian lain dalam hubungannya dengan sikap asertif menunjukan bahwa semakin tinggi kemampuan seseorang dalam bersikap asertif akan semakin tidak mudah terbawa dalam penyimpangan perilaku.

\section{METODE PENELITIAN}

Pendekatan yang digunakan dalam penelitian ini adalah pendekatan kuantitatif. "penelitian kuantitatif merupakan suatu penelitian yang menggunakan angka dalam mengumpulkan data dan dalam memberikan penafsiran terhadap hasilnya" ${ }^{6}$. Jenis penelitian yang digunakan dalam penelitian ini adalah penelitian korelasi. Dalam penelitian korelasi bertujuan untuk menemukan ada tidaknya hubungan dan apabila ada berapa eratnya hubungan serta berarti ada tidaknya hubungan itu ${ }^{7}$. Dalam penelitian ini bertujuan untuk menemukan hubungan antar variabel bebas yaitu Perilaku Asertif (X) dengan variabel terikat yaitu Kenakalan Remaja (Y).

${ }^{6}$ Arikunto, Suharsimi. Prosedur Penelitian Suatu Pendekatan Praktek. (Jakarta: Rineka Cipta. 2006) hlm:10.

7 Arikunto, Suharsimi. Prosedur Penelitian Suatu Pendekatan Praktek.

(Jakarta: Rineka Cipta.2007) hlm:239. 


\section{HASIL PENELITIAN DAN PEMBAHASAN}

\section{Hasil Penelitian}

Hasil pengukuran variabel perilaku asertif peserta didik diukur dengan menggunakan 42 item pertanyaan menunjukkan kisaran aktual antara 42-210, dengan deviasi standar 10,53 dihasilkan 5 kategori yaitu skor 42-75 termasuk kategori sangat rendah, skor 76-109 termasuk kategori rendah, skor 110-142 termasuk kategori cukup, skor 143-176 termasuk kategori tinggi, dan skor 177-210 termasuk kategori sangat tinggi.

Hasil skor diatas menunjukkan nilai rata-rata (mean) adalah 120,75 sehingga dapat diketahui bahwa perilaku asertif peserta didik kelas XI di SMAN 2 Masbagik termasuk dalam kategori tinggi. Sebanyak 88 responden dengan jumlah persentase 73,95\% termasuk dalam kategori tinggi, sebanyak 27 responden dengan jumlah persentase 22,69\% termasuk dalam kategori cukup, sebanyak 4 responden dengan jumlah persentase 3,36\% termasuk dalam kategori sangat tinggi, tidak ada perilaku asertif peserta didik yang termasuk dalam kategori rendah dan sangat rendah.

Adapun hasil deskripsi Prosentase perindikator dari variabel perilaku asertif peserta didik rata-rata perilaku asertif peserta didik kelas XI di SMAN 2 Masbagik termasuk dalam kategori tinggi, karena termasuk dalam berada pada interval antara 69\% - 84\% dalam kategori tinggi. Perilaku asertif merupakan sikap dimana seseorang mampu bertindak sesuai dengan keinginannya, membela haknya dan tidak dimanfaatkan orang lain. Bersikap asertif berarti mengomunikasikan apa yang kita inginkan secara jelas dengan menghormati hak pribadi kita dan orang lain. Sikap asertif merupakan ungkapan perasaan, pendapat, dan kebutuhan kita secara jujur dan wajar.

Dari 7 indikator yang termasuk dalam kategori tinggi sebanyak enam indikator yaitu dapat menerima dan memberi pujian, dapat menerima dan mengakhiri pembicaraan, dapat membela diri, dapat mengekspresikan pendapat pribadi dan dapat mengekspresikan perasaan yang menyenangkan dan tidak senang. Sedangkan yang termasuk dalam kategori cukup hanya ada satu indikator yaitu dapat mengekspresikan kemarahan dengan jumlah persentase sebesar 67,44 yang termasuk dalam kategori cukup. Indikator yang paling tinggi yaitu dapat menerima dan memberi pujian dengan jumlah persentase sebesar 79,1\%. Kemudian indikator dapat 
mengekspresikan perasaan yang menyenangkan dan tidak senang dengan jumlah persentase sebesar 74,25\%. Kemudian indikator dapat membela diri dengan jumlah persentase sebesar $74,16 \%$.

\section{Deskriptif Prosentase Kenakalan Remaja}

Hasil pengukuran variabel kenakalan peserta didik diukur dengan menggunakan 39 item pertanyaan menunjukkan kisaran aktual antara 39-195, dengan deviasi standar 6,37, dihasilkan 5 kategori yaitu skor 39-70 termasuk kategori sangat rendah, skor 71-101 termasuk kategori rendah, skor 102-132 termasuk kategori cukup, skor 133-163 termasuk kategori tinggi, dan skor 164-195 termasuk kategori sangat tinggi. Hasil skor diatas menunjukkan nilai rata-rata (mean) adalah 90,53 sehingga dapat diketahui bahwa perilaku asertif peserta didik kelas XI di SMAN 2 Masbagik termasuk dalam kategori cukup. Sebanyak 77 responden dengan jumlah persentase $64,71 \%$ termasuk dalam kategori cukup, sebanyak 42 responden dengan jumlah persentase 35,29\% termasuk dalam kategori tinggi, tidak ada kenakalan remaja yang termasuk dalam kategori sangat tinggi, sangat rendah dan sangat rendah.

Rata-rata kenakalan remaja pada peserta didik kelas XI di SMAN 2 Masbagik termasuk dalam kategori cukup, karena termasuk dalam berada pada interval antara 53\% - 68\% dalam kategori cukup. Kenakalan remaja merupakan perbuatan yang dilakukan oleh remaja dalam fase usia remaja (12-21 tahun) yang melanggar norma, baik norma sosial, norma hukum, maupun norma kelompok atau kaidah yang ditetapkan sekolah sehingga merugikan dirinya sendiri serta mengganggu ketentraman masyarakat. Dari 7 indikator, 3 diantaranya termasuk tinggi sisanya termasuk dalam kategori cukup. Indikator yang paling tinggi pada berbohong dengan jumlah persentase sebesar $69,56 \%$. Kemudian indikator yang paling rendah pada pergi tanpa ijinjumlah persentase sebesar $60,40 \%$.

\section{PEMBAHASAN}

\section{Deskripsi Perilaku Asertif Peserta didik}

Berdasarkan hasil penelitian menunjukkan bahwa perilaku asertif peserta didik sebanyak $73,95 \%$ berada pada kategori tinggi. Hal ini berarti perilaku yang menampilkan keberanian untuk jujur dan terbuka dalam menyatakan kebutuhan, perasaan dan pikirannya secara apa adanya tanpa menyakiti perasaan orang lain 
termasuk dalam kategori tinggi. Perilaku asertif peserta didik dalam hal ini merupakan sikap dimana seseorang mampu bertindak sesuai dengan keinginannya, membela haknya dan tidak dimanfaatkan orang lain.

Bersikap asertif berarti mengomunikasikan apa yang kita inginkan secara jelas dengan menghormati hak pribadi kita dan orang lain. Sikap asertif merupakan ungkapan perasaan, pendapat, dan kebutuhan kita secara jujur dan wajar. Kemampuan untuk bersikap asertif sangat penting dimiliki sejak dini, karena akan membantu kita untuk bersikap tepat menghadapi situasi dimana hak-hak kita dilanggar. Asertivitas adalah pernyataan diri yang positif, dengan tetap menghargai orang lain, sehingga akan meningkatkan kepuasan. Perilaku asertif merupakan perilaku berani menuntut hak-haknya tanpa mengalami ketakutan atau rasa bersalah serta tanpa melanggar hak-hak oranglain.

\section{Deskripsi Kenakalan Remaja Peserta didik}

Hasil penelitian juga diperoleh gambaran bahwa kenakalan remaja peserta didik kelas XI SMAN 2 Masbagik. Hal ini terlihat dari hasil analisis deskripsi persentase bahwa sebanyak 64,71\% responden termasuk dalam kategori cukup. Hal ini memberikan gambaran bahwa para peserta didik dalam hal kenakalan remaja belum begitu memprihatinkan, kenakalan remaja seperti suka merokok, pergi tanpa ijin, suka mencuri tidak begitu banyak dilakukan oleh peserta didik, peserta didik telah mengetahui hal-hal yang perlu dilakukan dan hal-hal yang tidak perlu dilakukan seperti mencuri, berbohong, berpakaian tidak sopan, merokok di sekolah, dan lainlain. Menurut pendapat Bentuk kenakalan gambaran secara umum tentang tingkah laku, yaitu : 1) Berbohong, 2) Pergi tanpa izin 3) Mencuri, 4) Berpakaian tidak pantas sangat minim, serta minum- minuman keras, 5) Merokok di sekolah 6) Berkelahi di Sekolah, 7) Penyalahgunaan Narkoba ${ }^{8}$. Pada usia mereka perilaku mereka memang belum melanggar hukum dalam arti yang sesungguhnya karena yang dilanggar adalah status-status dalam lingkungan primer (keluarga) dan sekunder (sekolah) yang memang tidak diatur oleh hukum secara terinci.

8 Gunarsa, Singgih. Psikologi Remaja. (Jakarta: Gunung Mulia.1981) hlm:16 


\section{Hubungan Perilaku Asertif dengan Kenakalan Remaja}

Hasil penelitian menunjukan bahwa terdapat hubungan yang signifikan antara perilaku asertif dengan kenakalan remaja pada peserta didik kelas XI SMAN 2 Masbagik, dengan nilai $-0,211$ dan $\mathrm{r}$ tabel $=0,176$. Hal ini menunjukan pola keterkaitan atau hubungan kedua variabel tersebut bersifat negatif, yang dapat diartikan apabila semakin tingkat asertivitas peserta didik, maka kenakalan remaja akan menurun, sebaliknya apabila tingkat asertivitas peserta didik mengalami penurunan, maka kenakalan remaja akan semakin meningkat.

Dengan demikian dapat diperoleh gambaran bahwa semakin tinggi perilaku asertif yang dimiliki individu, maka semakin rendah kenakalan remaja.yang ditimbulkan oleh individu, bahwa orang-orang yang memiliki asertivitas yang rendah akan semakin mudah terbawa dalam pengaruh lingkungan sekitar yang negatif atau perilaku menyimpang. Hal ini senada dengan penelitian lain dalam hubungannya dengan sikap asertif menunjukan bahwa semakin tinggi kemampuan seseorang dalam bersikap asertif akan semakin tidak mudah terbawa dalam penyimpangan perilaku. Sehingga dapat dikatakan Perilaku asertif erat kaitannya dengan kenakalan remaja.

Dapat disimpulkan bahwa apabila peserta didik memiliki asertivitas tinggi, maka peserta didik akan mampu mengkomunikasikan kebutuhan, keinginan, perasaan atau opini kepada orang lain dengan cara langsung dan jujur tanpa bermaksud menyakiti perasaan siapapun. Pada umumnya orang yang asertif dalam kehidupannya sehari-hari, mampu mengenal dirinya sendiri dengan baik, sehingga mampu menentukan pilihan keinginan dan tujuan hidupnya tanpa haras mempengaruhi orang lain. Remaja dengan asertivitas tinggi mampu membela dirinya sendiri maupun orang lain ketika diperlakukan tidak adil, mampu memberikan tanggapan terhadap masalah yang dihadapi yang dapat mempengaruhi hidupnya, serta mampu menyatakan keinginannya secara tegas terhadap orang lain. 


\section{KESIMPULAN}

Berdasarkan penelitian diketahui bahwa sebagian besar perilaku asertif responden termasuk kategori tinggi yaitu 73,95\%. Sebagian besar kenakalan remaja responden yang termasuk dalam kategori cukup 64,71\%. Hasil analisis korelasi diperoleh besarnya koefisien korelasi sebesar -0,211. Hasil uji korelasi menunjukkan bahwa rxy yang diperoleh sebesar -0,211 sedangkan pada $r$ tabel dengan $N=119$ sebesar 0,176. Karena nilai $\mathrm{r}$ hitung $>\mathrm{r}$ tabel $(-0,211>0,176)$ maka terdapat hubungan negatif antara perilaku sertif dengan kenakalan remaja. Sumbangan efektif variabel asertif sebesar 4,45\% terhadap kenakalan remaja pada peserta didik kelas XI SMAN 2 Masbagik.

\section{DAFTAR PUSTAKA}

Arikunto, Suharsimi. 2006. Prosedur Penelitian Suatu Pendekatan Praktek. Jakarta: Rineka Cipta.

Awaluddin. 2008. Assertive Behaviour on early teen. Psychology jurnal. Jakarta: Universitas Gunadarma.

Azwar, Saifudin. 2000. Skala Psikologi. Yogyakarta: Pustaka Pelajar.

Basri, Hasan. 1994. Remaja Berkualitas. Yogyakarta: Pustaka Pelajar.

Gunarsa, Singgih. 1981. Psikologi Remaja. Jakarta: Gunung Mulia.

Lloyd, Sam R. 1990. Mengembangkan perilaku Asertif yang positif. Jakarta: Binarupa Aksara.

Prabowo, Sumbodo. 2000. Membangun Perilaku Asertif pada Komunikasi antara perawat dan pasien. Psikodimensia. Semarang: Universitas Katholik Soegijapranata. Vol.1 No.1 (6-20)

Ratna. 2007. Sumbangan Perilaku Asertif terhadap harga diri pada karyawan. Jurnal Penelitian Psikologi. Jakarta: Universitas Gunadarma. Vol.1 No.1 (35-90)

Sarwono, Sarlito W. 2002. Psikologi Remaja. Jakarta: Raja Grafindo.

Sudarsono. 2004. Kenakalan Remaja. Jakarta: PT. Rineka Cipta.

Supratiknya, A. 1995. Komunikasi Antarpribadi Tinjauan Psikologis. Yogyakarta: Kanisius Willis, Sofyan. 2005. Remaja dan Masalabnya. Bandung: Alfabeta. 